\title{
Jihadi Anashid, Islamic State Warfare and the Agency of Sound
}

\author{
Luis Velasco-Pufleau
}

\section{Introduction}

On the morning of 10 November 2017, Islamic State (IS) supporters hijacked the Malmo frequency of the Swedish radio station Mix Megapol, one of the most important commercial radio stations in the country. They broadcasted for approximately 30 min a loop of "For the sake of Allah", , an IS English-speaking jihadi nashid ("Islamic chant" or "recitation", pl. anashid). People from Malmo called the radio station after listening to a melodic chant for male voices without instrumental accompaniment with lyrics supporting armed jihad and war. Part of the sophisticated IS global online propaganda and released by the IS media arm al-Hayat at the beginning of September 2015, this popular chant of IS militants urged individuals to fight for IS values and goals. It is the recitation of a "blood vengeance poem" (Fakhro 2020) which incites violence and urges the accomplishment of a jihadi obligation:

For the sake of Allah we will march through the gates,

of the paradise where our maidens await.

We are men that love death just as you love your life,

we are soldiers that fight in the day and the night.

Going forth, preparing to roar,

are the brothers of the light with kuffar in sight.

Their ranks are many and weapons are heavy

\footnotetext{
${ }^{1}$ In most cases, jihadi anashid are recognised and referred to by their incipit (the opening words of their text).
}

\section{Velasco-Pufleau $(\bowtie)$}

University of Bern, Bern, Switzerland

e-mail: luis.velasco-pufleau@wbkolleg.unibe.ch

(c) The Editor(s) (if applicable) and The Author(s), under exclusive license to 
but the soldiers of Allah are more than ready.

Defending the pride of our sisters who have cried,

for fearing none but the almighty as one

Their voices motivated the men who migrated,

to fulfil the duty of making God's words the greatest.

Oh my brothers jihad is the way,

to bring back the honour of our glorious days.

The promise of Allah will always remain,

that fighting for his sake is the ultimate gain.

Now the time has come for the battles to be won,

shahadah on our tongues as our hearts beat as one.

The sunnah is alive, Khilafah on the rise,

the flag of tawheed shining bright before our eyes.

Mainstream media depicted the IS nashid as a "pop-style song" used in IS propaganda videos "to try to lure fighters from the West to Iraq and Syria" (BBC 2017). However, this sort of depiction does not much help us to understand why an international criminal organisation which banned all kinds of music and musical instruments from their self-declared caliphate produce and broadcast jihadi chants across the globe.

Militant anashid constitutes "one of the most prominent elements of jihadi culture" (Hegghammer 2017a: 18). They are considered by Islamic scholars and jihadi militants as recitation of poetry rather than "music"-which, as I examine later, is forbidden by extremist Islamic ideology. The origins of militant anashid go back in particular to Islamist groups in 1970s Egypt and to jihadi armed groups in 1980s Afghanistan. However, as I develop in the next section, several influential Islamic scholars root militant anashid in Prophet Muhammad's military practices. Currently, it could be argued that a great variety of militant anashid are used, chanted and listened to by almost every jihadi armed group in the world. However, while most of these groups borrow militant anashid from a large historical corpus, part of IS propaganda and state-building strategy involves producing an original collection of jihadi anashid. This fact has "turned a new page on the role of anashid in jihadi culture" (Pieslak and Lahoud 2020: 281).

One of the particularities of IS jihadi anashid production is their multiple languages. IS structured their production in several media arms or branches: since 2013 Ajnad has produced most Arabic anashid and Qur'an recitations, while al-Hayat, al-Furqan and Furat have produced dozens of anashid in more than ten languages. These jihadi anashid in foreign languages are not translations from those in Arabic: they are written, composed and chanted by native speakers. Most of IS jihadi anashid have Arabic rhythms and musical elements, ${ }^{2}$ but anashid in other languages present musical elements from singers' and composers' musical cultures. However, their distribution strategy is generally the same: they are released first as stand-alone $\mathrm{mp} .3$ audio files on the internet and later they are used in several kinds of IS propaganda videos, targeting in particular the countries speaking the language of

${ }^{2}$ For an analysis of the musical profile of 17 IS Arabic jihadi anashid, see Pieslak and Lahoud (2020: 288-291). 
these videos and anashid. ${ }^{3}$ When anashid are integrated into propaganda videose.g. video-nashid, statement or execution videos - their sonic features are expanded with diegetic sound (human voices, Qur'an recitation, background sounds such as explosions, gunfire, shouting), voice-over and sound effects.

What are the beliefs behind this kind of sound composition? What is their role in the sacralisation of IS non-negotiable values? Do they encourage crime and violence? In this chapter I will address these questions. In order to do so, I first examine how the issue of the sacred nature of jihadi anashid has been developed in recent Salafi-related Islamic scholarship and how these discourses legitimise both the formal interdiction of music and the permitted use of jihadi anashid in warfare. I argue that the collective beliefs on the sacred nature of jihadi anashid are based on a particular conceptualisation of sound and its agency, which assumes that both music and Islamic anashid are able to influence the body and soul of listeners. Secondly, I explore testimonies on the role of jihadi anashid in IS warfare. While the banning of music by IS strengthens and perpetuates conflict, jihadi anashid listening and chanting are involved in the process of enemy identification, in coordinating militant practices and in the justification of violence. A careful examination of categories, beliefs and experiences behind the cultural-aesthetic dimension of jihadi ideology is central for understanding the rationale, values and commitment of jihadi militants.

\section{Banning Music, Chanting Jihadi Anashid: Why Does Sound Matter?}

For Islamic State leaders, the ban of all musical practices from the territories they controlled was a priority. When IS militants took control of Raqqa in January 2014, they issued a statement prohibiting all kinds of music and songs in private and public spaces. Just as other Islamist armed groups did in the past two decades, ${ }^{4}$ they argue that music and songs "are forbidden in Islam, as they prevent one from the remembrance of God and the Qur'an, and are a temptation and corruption of the heart" (El-Khoury 2014; Al-Tamimi 2015). IS extremist ideology is in line with most rigorist views on music and singing in Islam, in particular Salafi and Wahhabi traditions.

As Jonas Otterbeck points out, conservative and Islamist "hardliners" advance two main types of arguments against music. The first one is that "music destroys public morals", leading to chaos and the breakdown of society. The second is that

\footnotetext{
${ }^{3}$ They are a few exceptions to this rule. The IS video released after the Barcelona terrorist attacks in 2017, threatening Spain with more attacks, used IS jihadi anashid in French and not in Spanish (El País 2017). The reason could be that the IS did not have any Spanish jihadi anashid to put in the video at that time.

${ }^{4}$ Such as the Taliban in Afghanistan in 1996 (Baily 2004), and AQIM, MUJAO or Ansar ud-Dine in northern Mali in 2012 (Morgan 2013).
} 
music is "an evil distraction created by Satan and should be avoided altogether" (Otterbeck 2008: 223). These two arguments are developed through studies of the Qur'an, Sunna and the works of earlier Islamic scholars. Among recent scholars mobilised as authoritative sources in this topic, we find the Jordanian Muhammad Nasir ad-din al-Albani and the Canadian convert Abu Bilal Mustafa al-Kanadi. Both Islamic scholars legitimise the interdiction of music and singing, presenting all musical practices as "useless activities taking time from the worshipping of Allah" (Otterbeck 2008: 224). Furthermore, they assert that music has immense power over the human soul and argue that music in itself incites sinning. ${ }^{5}$

The critical issue here is the agency attributed to music and musical practices. Music, as an agent, is seen "as initiating causal sequences of a particular type" (Gell 1998: 16). ${ }^{6}$ In The Music Made Me Do It, a recent book published in Riyadh adhering to most conservative Islamic views on music, the author states that "music temporarily paralyzes and hypnotizes our minds just like narcotics such as alcohol, opium, heroin and cocaine" (Mushtaq 2011: 82). The prohibition of music and singing is justified because, among countless reasons, "there is a profound relationship between music and fornication" (p. 74), "singing has specific characteristics that weaken the heart, causing hypocrisy" (p. 81) and "music can successfully brainwash and condition its listener" (p. 95). Since agency is relational and interactional, these beliefs are ontological assumptions which reveal values and norms, organising complex relationships with music and sound in everyday life. More generally, the practices and prohibitions that result from these ontological assumptions are part of what Durkheim calls the "negative cult": a set of prohibitions which have the function of defining and separating what belongs to the domain of the profane and what is sacred (Durkheim 1912: 428).

If music incites sin, what about jihadi anashid? The rationale used by Islamic scholars to differentiate jihadi anashid to music is essential for the understanding of the use of jihadi anashid in violent confrontation and warfare. Both al-Albani and al-Kanadi advanced two interconnected types of arguments in order to justify anashid listening and chanting while prohibiting music listening. The first kind of argument, of an ontological type, is that anashid do not belong in the musical

\footnotetext{
${ }^{5}$ It is interesting to note here, in regard to the relationship between music and crime, that these arguments have similarities with those recently developed in the United States against specific kinds of music, such as hip-hop. In the context of "culture wars" (Bolton 1992; Ferrell 1999) since the 1980s and early 1990s, music has been accused of being a source of evil and criminal behaviour. "Is it fair to blame a musical composition for the increase in racial tension and the shooting incidents?", rhetorically asked the President of the National Association of Chiefs of Police, Dennis R. Martin. His answer was that "music has the power both to 'soothe the savage beast' and to stir violent emotions in man. [...] Yet the trend in American rock music for the last decade has been to promote ever more vile, deviant, and sociopathic behaviors" (Martin 1993: 159). For a discussion and refutation of the rationale behind this case, see the studies of Mark S. Hamm and Jeff Ferrell (1994) and Johnson and Cloonan (2009: 111-12).

${ }^{6} \mathrm{My}$ analysis here owes a debt to discussions I have had with Victor A. Stoichita. In a recent article on sound agency in violence, he develops the hypothesis that music constitutes an agentive resource for engaging different kinds of confrontation in combat situations (Stoichita 2020).
} 
domain but in the domain of recited poetry when unaccompanied by musical instruments. This idea goes back to the origins of the genre and its development in Islamic societies but has been subjected to important debates depending on the historical context and doctrines. ${ }^{7}$

The second argument, of a moral and contextual nature, relates to the beneficial effects on the listeners: the usefulness of the chants within the purifying religious enterprise in which the believers are engaged. Jihadi anashid "can incite the souls to defend Islam and encourage Jihad" (Al-Athari 2013: 146). Thus, Abu Bilal Mustafa al-Kanadi considers jihadi anashid as notable exceptions to the rule of prohibition of singing, and listening to music, not because anashid are not "music" but because of their value in militant jihad. According to this Islamic scholar, "during jihad and other struggles in the way of Allah, battle songs are of great spiritual and moral benefit to the warriors. In these circumstances, song incites heroism and valor and excites the Muslim people to 'take up the sword' for the cause of Allah" (Al-Kanadi 1986: 46).

Furthermore, al-Kanadi gives to jihadi anashid a sacred dimension by linking them directly to the practices of the Prophet Muhammad and some of his companions, who allegedly used them "to rouse up the feelings of the mujahidin before or on the way to combat" (Al-Kanadi 1986: 46). In particular, al-Kanadi asserts that the Prophet himself "raised his voice" to motivate and unify the hearts of mujahidin (fighters of jihad) during the Battle of the Ditch, which took place in 627 against the inhabitants of Mecca. At that time, the Prophet's chant "united the hearts of the believers and gave them courage and determination", allowing the victory of 2000 Muslims against 24,000 "enemies of Islam" (Al-Kanadi 1986: 48).

The sacred dimension of jihadi anashid, rooted in the Prophet's warfare practices, unifies the ontological argument and the moral argument mobilised to justify anashid listening. Neither music which corrupts hearts, nor chants that would distract believers from the truth of the Qur'an, jihadi anashid are a sacred sound that can be used both to encourage the mujahedin in the path of jihad and to weaken the hearts of the enemies of Islam. In IS propaganda, this idea has been conveyed on many occasions, for example, at the beginning of the IS video-nashid "Haya AlalJihad" [Let's go for jihad] produced by al-Hayat, the following statement is made: "Make supplication in order that Allah accepts, and this nashid may bomb the kuffar for real". From this perspective, anashid could be considered as sonic weapons that can reach and wound the enemy since militants are re-enacting the Prophet's warfare practices. This idea sheds new light on the Swedish radio frequency hijacking, giving to it a warfare dimension which is not evident for a "western" auditory.

Different kinds of music-making demarcate who belongs to the jihadi community and who is the "enemy". As Alenka Barber-Kersovan asserts, specific forms of music-making and singing provide "a communal basis for social relationships, and at the same time [they] also draw demarcation lines between different social

\footnotetext{
${ }^{7}$ On this topic see the studies of Amnon Shiloah (1995), Kristina Nelson (1985: 38-51), Nelly Lahoud (2017: 43-48), Jonathan Pieslak (2017: 63-69), and Pieslak and Lahoud (2020).
} 
agglomerations, whereby 'we' are mostly connoted in a positive sense and 'the others' in a negative sense" (Barber-Kersovan 2004: 7). As a result, musicians became a target inside and outside of IS territories. It was confirmed on many occasions, such as when the French jihadi militant Rachid Kassim called for attacks on, among others, "rappers and musicians". He argued that they are "Islam's enemies" because "all they do is manipulate the truth" (Amarasingam 2016). Music is a mark of the enemy.

\section{Jihadi Anashid and IS Warfare}

If the ontology of jihadi anashid is related to the sacred, what are the social and emotional conditions in which militants are chanting and listening to them? Several testimonies suggest that jihadi anashid are listened to and chanted during combat and training, as a part of IS warfare. In a documentary on Islamic State (IS) child soldiers, Muhammad, a 13-year-old boy from Raqqa, tells how he was recruited for his voice after he won a local anashid contest. The contest was organised by an Iraqi IS operative known as Abu Muhammad al-Baghdadi and aimed to enrol munshidun (reciters, sg. munshid) to chant on the frontline. Muhammad won the contest because of his capacity to reach out and move the auditory with his voice, joining the IS and taking the nom de guerre (kunya) Abu Al-Abbas Al Raqqawi. He learned IS jihadi anashid and chanted them during combat in order "to raise the fighters' morale" (Dandois and Trégan 2017). Muhammad asserts that when fighters hear a jihadi nashid on the frontline, "it lifts their spirits: they feel confident, and important" (Dandois and Trégan 2017). ${ }^{8}$

This use is rooted in late twentieth century jihadi military practices and warfare. In recent contributions to the study of jihadi anashid, Jonathan Pieslak and Nelly Lahoud noted that the use of anashid in fighters' training and preparation for attacks goes beyond the recent use by IS militants. Regarding attacks related to Al-Qaida, Khalid al-Awhali, one of the two suicide bombers of the US embassy attack in Nairobi in 1998, was listening to a nashid "for motivation in preparing to die on the way to the embassy" (Lahoud 2017: 51; Pieslak 2015: 44). Tsarnaev brothers, the authors of the Boston Marathon bombing, listened to militant anashid in the car hijacked on 18 April 2013 during the manhunt following the attack (Pieslak and Lahoud 2020: 275). Similarly, Thomas Hegghammer recounts the case of Hammad Khurshid, a Danish citizen who produced explosives with the intention of carrying out a bomb attack in 2007, while listening to and chanting jihadi anashid (Hegghammer 2017b: 189).

Media and intelligence agencies have noticed the relationship between jihadi anashid and the preparation of IS related recent terrorist attacks. After the terrorist

\footnotetext{
${ }^{8}$ For an examination of the main themes developed in IS jihadi anashid, see the studies of Nelly Lahoud (2017), Jonathan Pieslak and Nelly Lahoud (2020), and Henrik Gråtrud (2016).
} 
attack in the Brussels metro station on 22 March 2016, police investigators found on the computer of the suicide bomber Khalid El-Bakraoui "many chants and videos to the glory of jihad" (AFP 2016). Similarly, the examination of the Internet browser history of Mohamed Lahouaiej-Bouhlel, the author of the lorry attack of the evening of 14 July 2016 in Nice, showed that for several weeks he had carried out almost daily searches on "videos of recitation of Qur'anic verses and anashid-religious chants that jihadi terrorist organisations, including Daesh [IS], use as propaganda material" (Molins 2016).

The connexion in Lahouaiej-Bouhlel case between jihadi anashid and the Qur'an recitation is significant. Rooting jihadi anashid in the Prophet's sonic practices connect them to the Qur'an recitation and tajwid-the system of rules regulating its correct elocution. According to Kristina Nelson, the tajwid "is believed to be the codification of the sound of the revelation as it was revealed to the Prophet Muhammad, and as he subsequently rehearsed it with the Angel Gabriel. Thus, the sound itself has a divine source and significance, and, according to Muslim tradition, is significant to the meaning" (Nelson 1985: 14-15). This sacred origin of sound gives to Qur'an recitation a strong transformative power, which could be considered as morally opposite of the corruption of the sound of music. Jihadi anashid find their legitimation as lawful sound in regard to this particular sound ontology.

The combination of jihadi anashid with Qur'an recitation in warfare is not new. Older jihadi testimonies suggest that militants have combined anashid listening and chanting with Qur'an recitation on a daily basis, training camps often offering courses on tajwid. It seems that jihadi militants have even used Qur' an recitation in combat, such as in 1980s Afghanistan when a group of Arabs 'recited the Qur' an on loudspeakers as a form of psychological warfare against the enemy", or in Somalia around 2006 when the Al-Qaida operative Fadil Harun "recited the Qur' an to boost the morale of his own men" (Hegghammer 2017b: 184). These listening and performing practices indicate that jihadi militants constitute a community of listeners, which can share an "auditory culture" (Kane 2015), values and ontological assumptions about sound.

Islamic State propaganda continues these practices and actively promotes the narrative that IS militants combined jihadi anashid listening and chanting with Qur'an recitation as part of their training for combat and suicide attacks. This narrative is mobilised in an article published in the second issue of the IS magazine Rumiyah about the attack at the Holey Artisan Bakery in Dhaka (Bangladesh) on 1 July 2016. The article asserts that, during his training for the suicide operation he carried out, the leader of the five suicide attackers Abu Rahiq al-Bengali

used to recite Qur'an daily and pray the night prayers regularly, despite the tiredness from the heavy work-out session at night and the obligatory fast in the days of the blessed month of Ramadan. He used to get very moved by the famous Islamic State nashid "Qariban, Qariban" [Soon, soon] and would read the lyrics during the training period and say, "it is exactly what we will do to the Crusaders, bi idhnil-lah" (Rumiyah, $\mathrm{n}^{\circ} 2$, p. 10). 
This narrative seeks to reinforce the idea of the sacred nature of their actions, warfare and goals. Furthermore, the IS jihadi nashid might be considered as an explicit "performative utterance" (Fischer-Lichte 2008: 24), since it anticipates and performs the actions of combatants, while justifying and sacralising their retaliation acts as a part of a global war. It is significant that the IS media arm Ajnad Foundation has been responsible for producing and distributing both jihadi anashid and Qur' an recitation, highlighting the connexion between the two sorts of sacred sound which have been systematically used in IS audiovisual propaganda. A recent study on a sample set of 755 propaganda videos released by IS media in 2015 confirmed the use of anashid and Qur'an recitation (live or recorded) in more than $85 \%$ of the videos (Pieslak et al. 2019). Among these videos, anashid were far more prevalent than Qur'an recitations, being more than 88\% of all "soundtrack events" (Pieslak et al. 2019: 3).

Frequently, Qur'an recitation or oral quotes introduce IS execution videos or audio statements, claiming the divine nature of IS actions and retaliation acts. This is the case of the video staging the public execution of 25 Syrian soldiers in Palmyra's Roman Theatre in May 2016, which is introduced by a recitation of verse 14 of the surah "At-Tawbah" (The Repentance): "Fight them; Allah will punish them by your hands and will disgrace them and give you victory over them and satisfy the breasts of a believing people". As I discussed in a previous article, this is also the case of the IS audio statement of the 2015 Paris attacks, where two oral quotes from Qur'anic verses are inserted before and after the speech, introducing and closing the spoken voice on a French jihadi nashid background (VelascoPufleau 2015). The first Qur' an quote in this IS declaration is an excerpt from verse two of the surah "Al-Hashr" (The Exile): "And they thought that their fortresses would protect them from Allah; but [the decree of] Allah came upon them from where they had not expected, and He cast terror into their hearts [so] they destroyed their houses by their [own] hands and the hands of the believers. So take warning, O people of vision". The second Qur' an quote, which closes the speech and is followed by the nashid, is an excerpt from verse eight of the surah "Al-Munafiqun" (The Hypocrites): "And to Allah belongs [all] honor, and to His Messenger, and to the believers, but the hypocrites do not know". The function of uttering these Qur'anic verses is to establish a symmetrical relationship between the IS terrorist attacks and key events of the Prophet's life in order to give the former a teleological meaning. It could be argued that IS jihadi anashid have been used both for "sacralising" IS actions claimed in their propaganda and for bringing forth the situations they are referring to.

\section{Conclusion}

Social actors use music and sound as symbolic resources in order to make sense of their actions and situations in which they are engaged. Jihadi anashid are performative utterances which construct a social reality. Further examination of the 
significance of jihadi anashid in jihadi militancy and warfare would need larger empirical studies. However, it is possible to assert that militants use jihadi anashid as resources for constituting their subjectivity, since these chants play a certain role in defining the boundaries of who belongs to the group of "righteous" and who are the enemy. Jihadi militants chant and listen to jihadi anashid to frame and stage their engagement in specific kinds of confrontation, as it has been examined for other combatants' musical practices in contemporary armed conflicts (Daughtry 2015; Nuxoll 2015; Stoichita 2020).

When thinking about the relationship between music and crime, it is more useful to think about music as a symbolic resource which people can mobilise than as an object affecting human will by itself. Music provides specific affordances, it is a resource for "world building" (DeNora 2000: 44). Therefore, it is fundamental to analyse the process of appropriation of music as a resource, particularly people's musical practices, material conditions of listening and interaction rituals in which music and sound are embedded. This process is relational, involving particular sound ontologies and values shared by a community of listeners. Through the analysis of the musical and sound practices of jihadi militants, the fields of musicology and ethnomusicology can contribute to the understanding of militants' sacred values, the uses of sound in warfare as well as the dynamics of identity construction of "devoted actors" in contexts of violent conflict (Atran 2016). This knowledge is essential in order to comprehend the rationale for justification and the mechanisms of bringing about extreme violence.

\section{References}

AFP (2016) 'Khalid El-Bakraoui, qui s’est fait sauter dans le métro de Bruxelles, avait été arrêté... mais relâché!' La Capitale. 5 June on: http://www.lacapitale.be/1589840/article/2016-06-05/ khalid-el-bakraoui-qui-s-est-fait-sauter-dans-le-metro-de-bruxelles-avait-ete-ar.

Al-Athari, A. (2013) Singing \& Music in Islamic Perspective. Riyadh: Darussalam, on: http:// darussalam.com/singing-and-music-in-islamic-perspective.html.

Al-Kanadi, Abu Bilal M. (1986) The Islamic Ruling on Music and Singing: In Light of the Quraan, the Sunnah and the Consensus of Our Pious Predecessors. Jeddah: Bilal M. Al-Kanadi \& Broths

Al-Tamimi, Aymenn Jawad (2015) 'Statement Concerning the Prohibition on Music, Singing and Photos on Shops'. Archive of Islamic State Administrative Documents, on: http://www.aymennjawad.org/2015/01/archive-of-islamic-state-administrative-documents.

Amarasingam, A. (2016) 'GUEST POST: An Interview with Rachid Kassim, Jihadist Orchestrating Attacks in France', in: JIHADOLOGY (blog). 18 November, on: http://jihadology.net/2016/11/18/guest-post-an-interview-with-rachid-kassim-jihadist-orchestratingattacks-in-france/

Atran, S. (2016) 'The Devoted Actor: Unconditional Commitment and Intractable Conflict across Cultures', in: Current Anthropology vol. 57 (S13), pp. 192-203, on: https://doi. org/10.1086/685495

Baily, J. (2004) 'Music Censorship in Afghanistan before and after the Taliban'. In: Korpe, M. (ed) Shoot the Singer!: Music Censorship Today, pp. 19-28. London; New York: Zed Books 
Barber-Kersovan, A. (2004) 'Music as a Parallel Power Structure'. In: Korpe, M. (ed) Shoot the Singer!: Music Censorship Today, pp. 6-10. London; New York: Zed Books

BBC (2017) 'Swedish Radio "Hijacked by IS Propaganda"'. BBC News, 10 November, sec. Europe, on: https://www.bbc.com/news/world-europe-41946784.

Bolton, R. (ed) (1992) Culture Wars: Documents from the Recent Controversies in the Arts. 1st ed. New York: New Press

Dandois, T. \& F.-X. Trégan (2017) Ashbal - Les Lionceaux Du Califat. France: Memento \& Arte, on: http://www.arte.tv/fr/videos/071376-000-A/ashbal-les-lionceaux-du-califat

Daughtry, M. (2015) Listening to War: Sound, Music, Trauma, and Survival in Wartime Iraq. New York: Oxford University Press

DeNora, T. (2000) Music in Everyday Life. Cambridge: Cambridge University Press

Durkheim, E. (1912) Les Formes Élémentaires de La Vie Religieuse. Paris: Félix Alcan

El País (2017) 'ISIS Warns of More Attacks in Spain in First Spanish-Language Video'. El País, 24 August 2017, sec. Inenglish, on: https://elpais.com/elpais/2017/08/24/inenglish/1503561689_277218.html

El-Khoury, J. (2014) 'ISIS Bans Music, Imposes Veil in Raqqa'. Al-Monitor. 21 January, on: http:// www.al-monitor.com/pulse/security/2014/01/isis-raqq-ban-music-smoking-impose-veil.html.

Fakhro, D. (2020) Tracing the Movement of the Blood Vengeance Theme within Arabic Poetry: From the Classical Poetic Tradition to the Present, in: British Journal of Middle Eastern Studies vol. 47, no. 3, pp. 402-422, on: https://doi.org/10.1080/13530194.2018.1500270.

Ferrell, J. (1999) Cultural Criminology, in: Annual Review of Sociology vol. 25, pp. 395-418

Fischer-Lichte, E. (2008) The Transformative Power of Performance: A New Aesthetics. Abingdon: Routledge

Gell, A. (1998) Art and Agency: An Anthropological Theory. Oxford: Oxford University Press

Gråtrud, H. (2016) Islamic State Nasheeds As Messaging Tools, in: Studies in Conflict \& Terrorism vol. 39, no. 12, pp. 1050-70, on: https://doi.org/10.1080/1057610X.2016.1159429

Hamm, M. \& J. Ferrell (1994) Rap, Cops, and Crime: Clarifying the "Cop Killer" Controversy, in: ACJS Today vol. 13, no. 1, pp. 1, 3, 29

Hegghammer, T. (2017a) Introduction: What Is Jihadi Culture and Why Should We Study It?, in: Hegghammer, T. (ed) Jihadi Culture. The Art and Social Practices of Militants Islamists, pp. 1-21, Cambridge: Cambridge University Press

Hegghammer, T. (2017b) Non-Military Practices in Jihadi Groups, in: Hegghammer, T. (ed) Jihadi Culture. The Art and Social Practices of Militants Islamists, pp. 171-201. Cambridge: Cambridge University Press

Johnson, B. \& M. Cloonan (2009) Dark Side of the Tune: Popular Music and Violence. Farnham: Ashgate

Kane, B. (2015) Sound Studies without Auditory Culture: A Critique of the Ontological Turn, in: Sound Studies vol. 1, no. 1, pp. 2-21, on: https://doi.org/10.1080/20551940.2015.1079063.

Lahoud, N. (2017) A Cappella Songs (Anashid) in Jihadi Culture, in: Hegghammer, T. (ed) Jihadi Culture. The Art and Social Practices of Militants Islamists, pp. 42-62. Cambridge: Cambridge University Press

Martin, D. (1993) The Music of Murder, in: William \& Mary Bill of Rights Journal, vol. 2, no.1, pp. $159-63$

Molins, F. (2016) Conf. de Presse Du 18 Juillet 2016 Du Procureur de La République de Paris, F. Molins, France 3 Côte d'Azur. 18 July, on: https://youtu.be/1T7sYZBr5-U

Morgan, A. (2013) Music, Culture and Conflict in Mali. Copenhagen: Freemuse

Mushtaq, G. (2011) The Music Made Me Do It. An in-Depth Study of Music through Islam and Science. Riyadh: International Islamic Publishing House

Nelson, K. (1985) The Art of Reciting the Qur'an. Austin: University of Texas Press

Nuxoll, C. (2015) "We Listened to It Because of the Message": Juvenile RUF Combatants and the Role of Music in the Sierra Leone Civil War, in: Music and Politics vol. IX, no. 1, on: https:// doi.org/10.3998/mp.9460447.0009.104 
Otterbeck, J. (2008) Battling over the Public Sphere: Islamic Reactions to the Music of Today, in: Contemporary Islam vol. 2, no. , pp. 211-28, on: https://doi.org/10.1007/s11562-008-0062-y

Pieslak, J. (2015) Radicalism and Music: An Introduction to the Music Cultures of al-Qa'ida, Racist Skinheads, Christian-Affiliated Radicals, and Eco-Animal Rights Militants. Middletown: Wesleyan University Press

Pieslak, J. (2017) A Musicological Perspective on Jihadi Anashid, in: Hegghammer, T. (ed) Jihadi Culture. The Art and Social Practices of Militants Islamists, pp. 63-81. Cambridge: Cambridge University Press

Pieslak, J. \& Lahoud N. (2020) The Anashid of the Islamic State: Influence, History, Text, and Sound, in: Studies in Conflict \& Terrorism vol. 43, no. 4, pp. 274-299, on: https://doi.org/1 0.1080/1057610X.2018.1457420.

Pieslak, J., B. Pieslak, \& A. Lemieux (2019) Trends of Anashid Usage in Da'esh Video Messaging and Implications for Identifying Terrorist Audio and Video, in: Studies in Conflict \& Terrorism, January, pp. 1-16, on: https://doi.org/10.1080/1057610X.2018.1545828

Shiloah, A. (1995) Music in the World of Islam: A Socio-Cultural Study. Detroit: Wayne State University Press

Stoichita, V. (2020) Affordance to Kill: Sound Agency and Auditory Experiences of a Norwegian Terrorist and American Soldiers in Iraq and Afghanistan, in: Transposition, no. Hors-série 2, on: https://doi.org/10.4000/transposition.4065

Velasco-Pufleau, L. (2015) Après les attaques terroristes de l'État islamique à Paris. Enquête sur les rapports entre musique, propagande et violence armée, in: Transposition, no. 5, on: https:// doi.org/10.4000/transposition.1327. 